\title{
Drugs for psychosis and mood: unique actions at D3, D2, and D1 dopamine receptor subtypes
}

\author{
Stephen M. Stahl \\ ISSUE: \\ Drugs for psychosis and mood that bind dopamine D2 receptors can be classified \\ not only by whether they also block serotonin $2 \mathrm{~A}$ receptors, but by whether they \\ also bind D3 or D1 receptors.
}

\section{Take-Home Points}

- Drugs that bind D2 receptors are treatments for psychosis and mood; for many years they have been pharmacologically classified either as those that also block serotonin $5 \mathrm{HT} 2 \mathrm{~A}$ receptors or as those that do not.

- A new classification of drugs for psychosis and mood that bind D2 receptors creates 3 different categories according to which dopamine receptors are bound: those that preferentially bind D2 receptors (most of these agents), those that also bind D3 receptors effectively (cariprazine $>$ blonanserin), and those that also bind D1 receptors (asenapine, clozapine, and olanzapine > quetiapine and ziprasidone).

- These 3 classes theoretically have functional differences with potential clinical implications, such as improvement in cognition, motivation, and mood from D3 antagonism/ partial agonism and cognitive dysfunction from D1 antagonism.

\section{Introduction}

Classification of psychotropic drugs is an ever-evolving process, most recently culminating in neuroscience-based nomenclature $(\mathrm{NbN})$, which is built upon pharmacological mechanism of action and not upon clinical indication. ${ }^{1,2}$ So-called "second-generation" or "atypical" antipsychotics have long been pharmacologically differentiated from "first-generation" or "conventional" antipsychotics by their potent binding to serotonin $2 \mathrm{~A}$ receptors as well as to D2 dopamine receptors. ${ }^{3}$ Now these same agents that treat psychosis and mood can also be classified according to which dopamine receptors (D1, D2, D3) they bind (Figures 1-9 and Table 1). ${ }^{4,5-8}$ The presence or absence of actions at various dopamine receptor subtypes changes their neurobiological mechanisms and, potentially, their clinical effects. ${ }^{4}$

\section{A New Classification of Drugs Based on D1, D2, and D3 Binding}

Here we categorize the so-called "second generation/ atypical antipsychotics" in a new way: into 3 major categories based on their dopamine receptor subtype binding profiles (Table 1). ${ }^{4-8}$ By definition, all 13 of these agents bind to D2 receptors (Table 1 and Figure 4 ). However, some of these agents act effectively at D1 receptors as well as D2 receptors (Table 1 and Figures 1 and 3); others act effectively at D3 receptors as well as D2 receptors (Table 1 and Figures 2 and 5). ${ }^{5-8}$ Clinically relevant binding at D1 and D3 receptors is based not only on how potently drugs bind to these receptors compared to how potently they bind to D2 receptors (Figures 1 and 2), but also how their binding potencies for D1 and D3 receptors compare to those of dopamine itself at these same receptors (Figures 3-5).

\section{Drugs with Mostly D2 Antagonism/Partial Agonism}

All drugs in Table 1 are more potent than dopamine for D2 receptors, and some are far more potent (Figure 4 and Table 1). This means that dopamine is less effective at competing for D2 receptors than are any of these drugs. At low levels of dopamine, D2 binding of all these drugs is therefore predominant. However, if dopamine floods 


\section{BRAINSTORMS - Clinical Neuroscience Update}

Figure 1. This figure shows the dopamine D1 receptor affinity relative to the dopamine D2 receptor affinity for drugs that treat psychosis and mood. No drug has a higher affinity for D1 than it does for D2, and some have very low affinities for D1 receptors relative to $\mathrm{D} 2$.

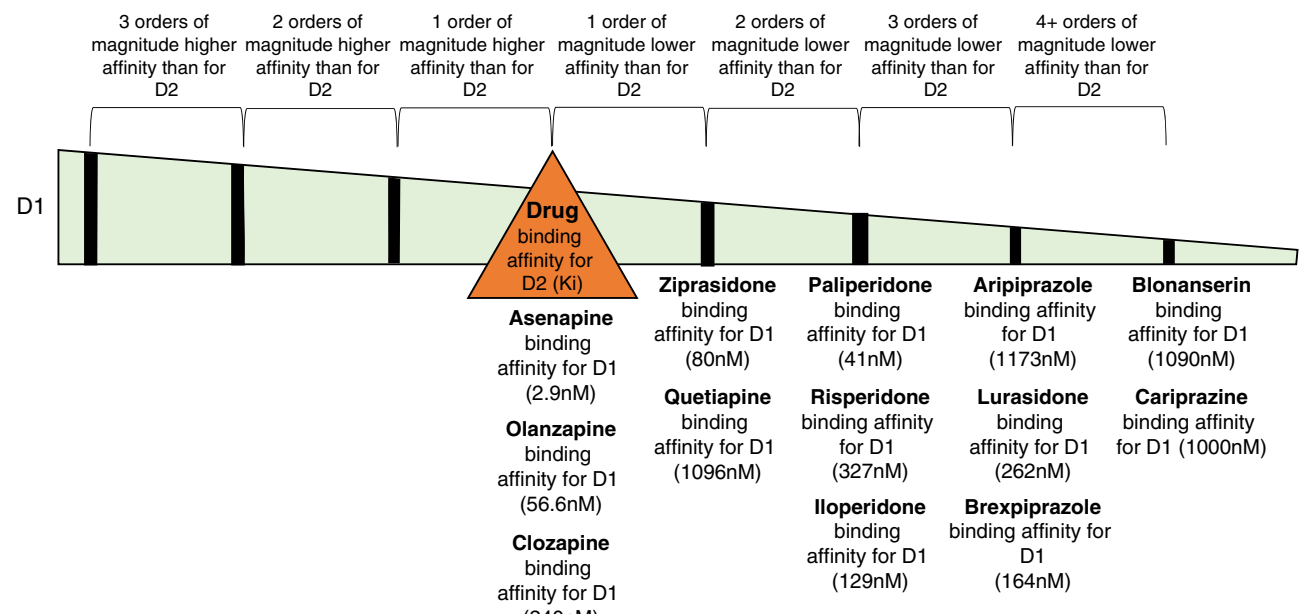

Figure 2. This figure shows the dopamine D3 receptor affinity relative to the dopamine D2 receptor affinity for drugs that treat psychosis and mood. Only one agent, cariprazine, has higher affinity for D3 receptors than for D2 receptors. All other agents are essentially equal or lower in affinity for D3 compared to D2.

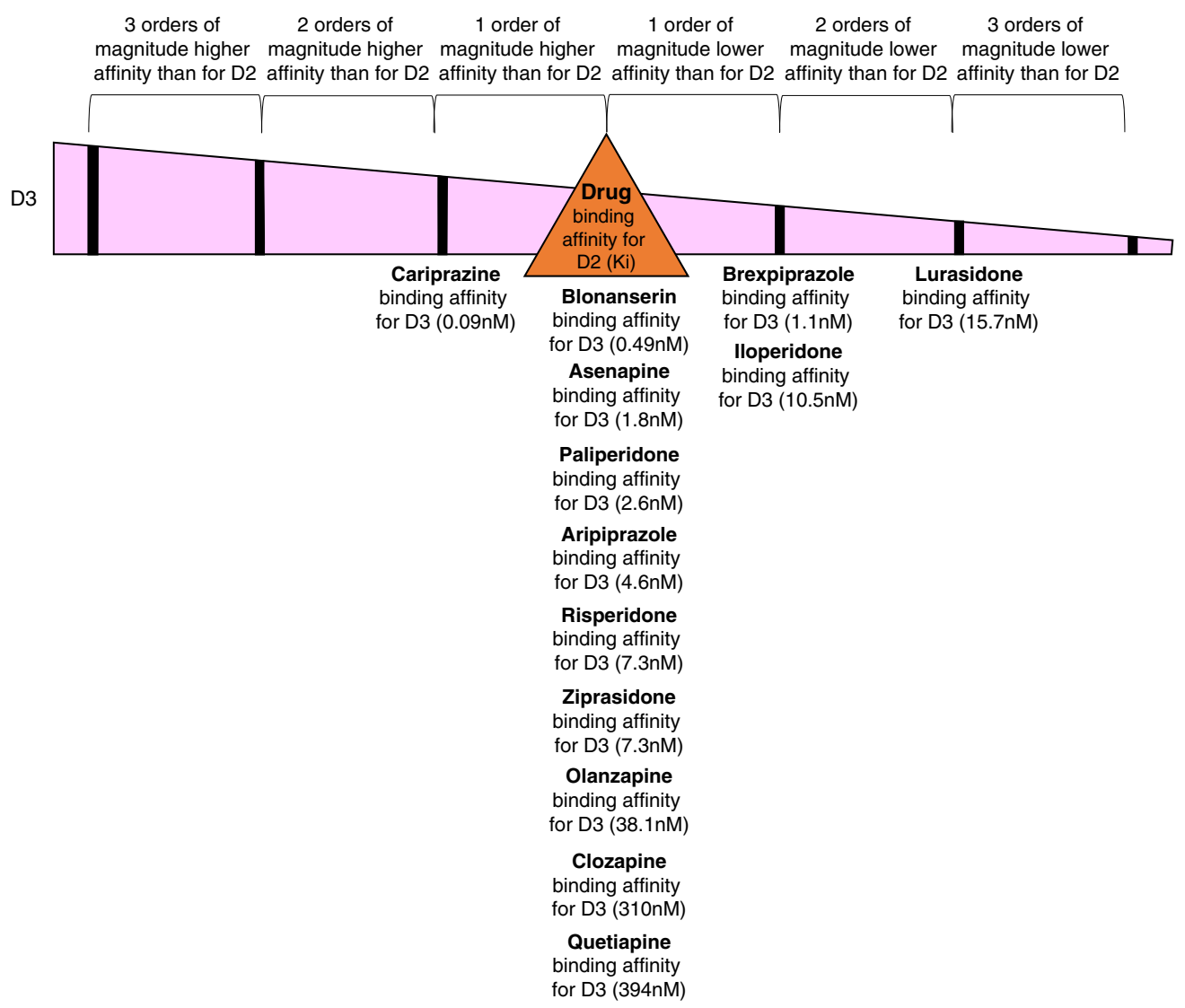




\section{BRAINSTORMS - Clinical Neuroscience Update}

Figure 3. This figure shows the relative affinities of drugs for psychosis and mood for D1 receptors compared to the affinity of dopamine itself for D1 receptors. All agents have equal or higher affinity for the D1 receptor than does dopamine itself.

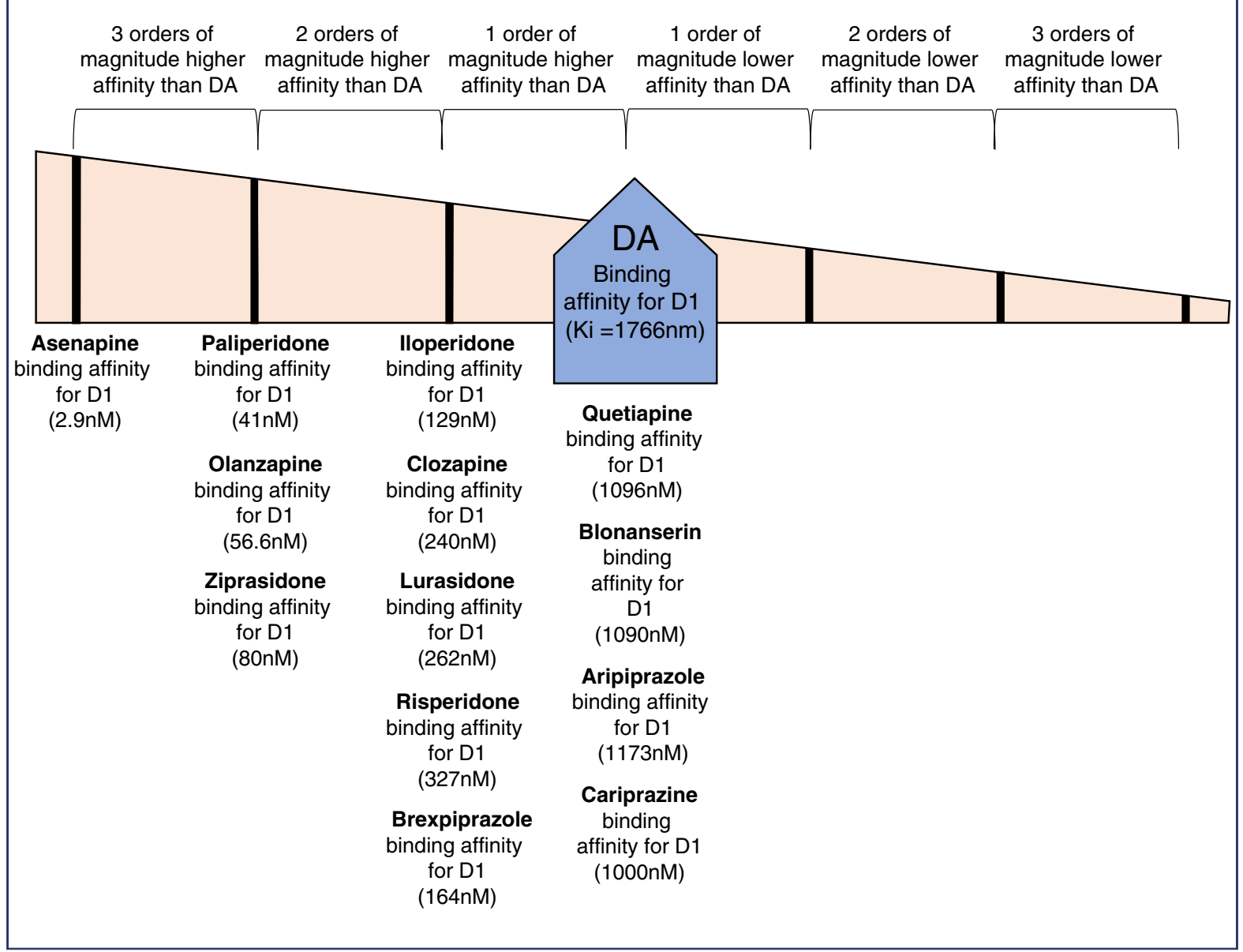

the synapse during neurotransmission or when the stimulants methylphenidate or amphetamine are given, sufficiently large amounts of dopamine are released so that D2 binding by antipsychotics is reduced by mass action of dopamine predominating over its lower affinity. ${ }^{9-11}$ Thus, the amount of D2 binding of drugs for psychosis will depend not only on binding affinity and dose of the drug, but also on the amount of dopamine present. In general, D2 antagonists/partial agonists are dosed so that the net binding to D2 receptors in the presence of whatever amount of dopamine is released in schizophrenia patients is $60 \%$ or more. ${ }^{3,12}$

All drugs in Table 1 bind to all 3 dopamine receptors D1, D2, and D3 to some extent (Figures 1-5), but those that bind D1 and D3 receptors with much lower affinity than they bind D2 receptors will likely not have clinically relevant binding at D1 and D3 receptors. Clinically relevant binding at D1 and D3 receptors is especially unlikely if drug affinities for these receptors are also lower than dopamine's own affinities for these receptors. That is, if dopamine's affinity for a receptor is greater than that of the drug, dopamine would successfully compete with the drug for the receptor if dopamine and the drug are present at similar concentrations. Taking all these factors into consideration, most drugs for psychosis and mood that bind to D2 receptors are D2-preferring. This includes 8 of the 13 drugs in Table 1 (see also Figures 1-5 and 9).

The functional outcomes of antagonist/partial agonist actions at D2 dopamine receptors are the best characterized receptor actions for any drug that binds to any dopamine receptor. Namely, D2 antagonist/partial agonist actions in the nucleus accumbens are well known to reduce positive symptoms of psychosis, whereas these same D2 actions in the motor striatum can result in druginduced parkinsonism in the short term and tardive dyskinesia in the long term (Figure 7). ${ }^{3}$ 


\section{BRAINSTORMS—Clinical Neuroscience Update}

Figure 4. This figure shows the relative affinities of drugs for psychosis and mood for D2 receptors compared to the affinity of dopamine itself for D2 receptors. All agents have equal or higher affinity for the D2 receptor than does dopamine itself. Many agents have higher or much higher affinities for D2 compared to dopamine.

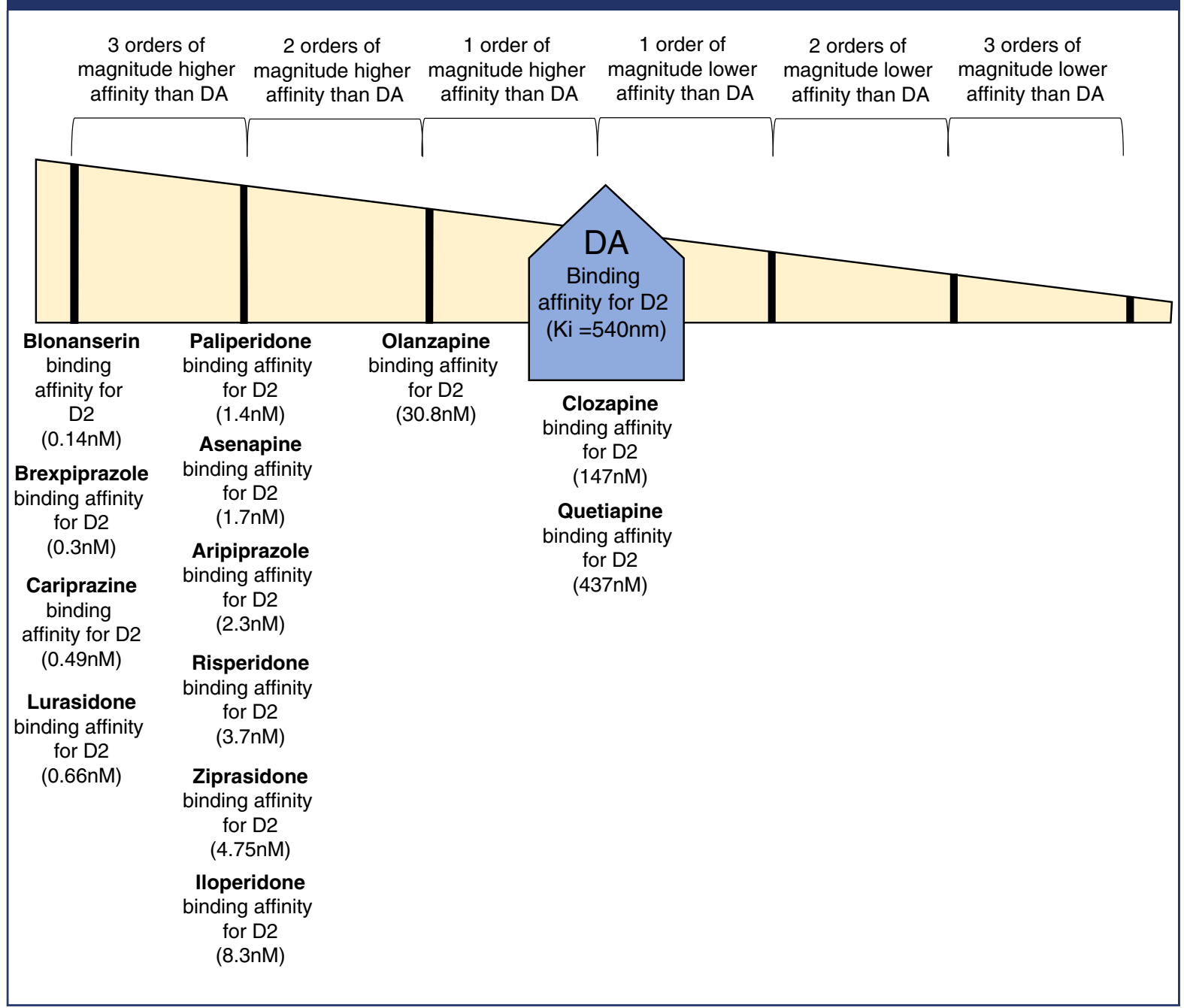

\section{Drugs with Effective D1 Antagonism (Plus D2 Antagonism/Partial Agonism)}

Some drugs in Table 1 bind to D1 receptors with affinities that suggest potentially clinically relevant occupancy at antipsychotic dose levels. That is, their D1 affinities are close to their D2 affinities (Figure 1), and greater than dopamine's affinity for D1 receptors (which is relatively low) (Figure 3). Taken together, 3 agentsasenapine, olanzapine, and clozapine-are most likely to have clinically meaningful D1 antagonism at antipsychotic dosing levels (Table 1). Ziprasidone and quetiapine are next in order of having possible D1 binding at clinical doses because their affinities are within 1 one order of magnitude of their affinities for D2 receptors, and higher than dopamine's affinity for D1 receptors (Figures 1 and 3). By the time a drug has binding that is 2 orders of magnitude (paliperidone, risperidone, and iloperidone) or higher affinity for D2 over D1 (Figure 1), there is diminishing probability of D1 binding.

Only relatively recently have the effects of D1 dopamine receptor blockade been characterized. In the prefrontal cortex, D1 receptors are the major postsynaptic dopamine receptor subtype, unlike the nucleus accumbens and motor striatum, which are rich in both D2 and D1 receptors. ${ }^{4}$ In animal models, including primates, D1 activity must be optimized in the prefrontal cortex for best cognitive effects (Figure 6). ${ }^{4,13-16}$ Both too much as 


\section{BRAINSTORMS - Clinical Neuroscience Update}

Figure 5. This figure shows the relative affinities of drugs for psychosis and mood for D3 receptors compared to the affinity of dopamine itself for D3 receptors. All but 2 agents have affinities for D3 within 1 order of magnitude higher or lower than does dopamine itself. One agent has very much higher affinity for D3 than does dopamine, namely cariprazine; 1 agent has somewhat higher affinity, namely blonanserin.

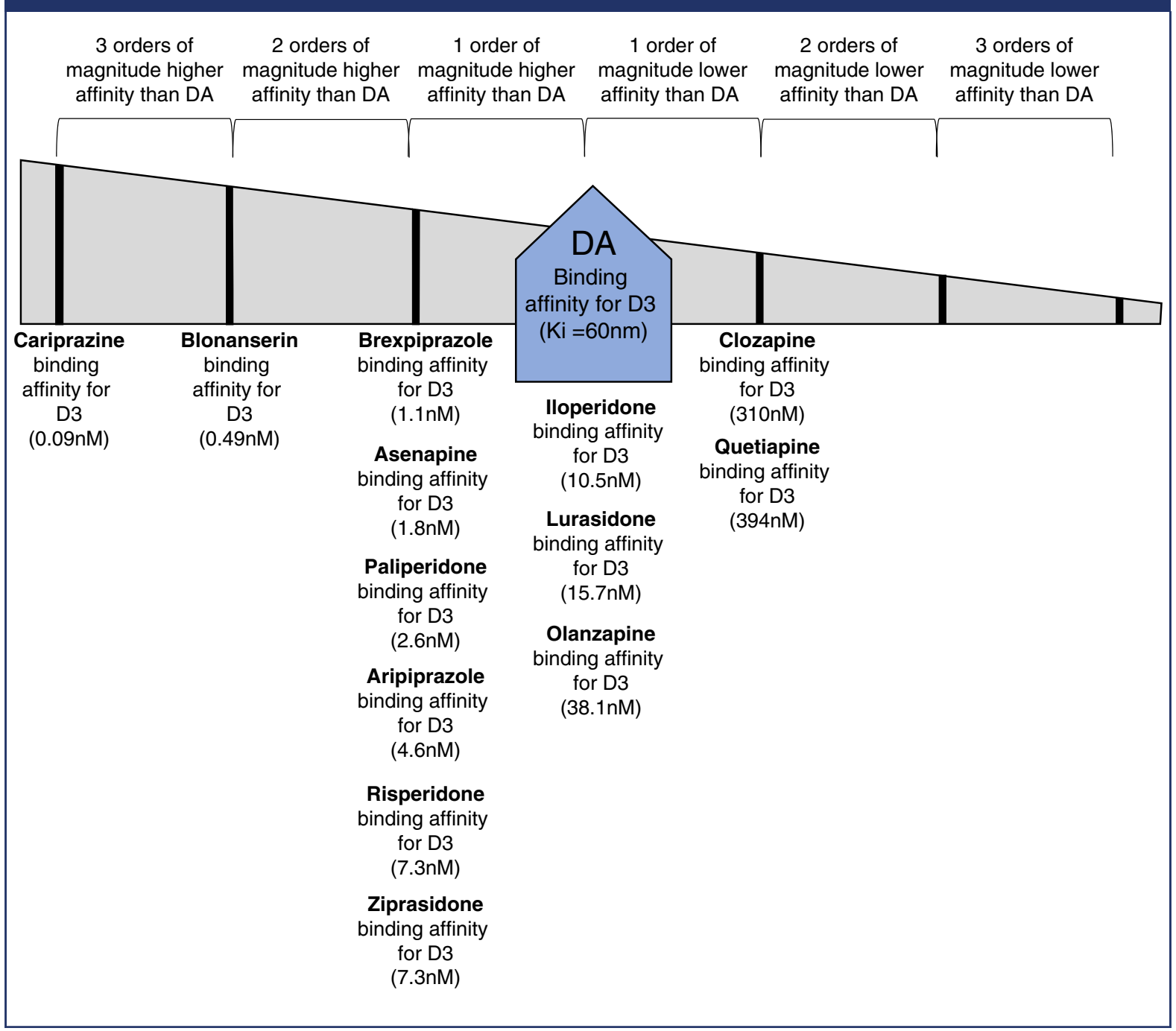

well as too little dopamine activity at cortical D1 receptors are associated with cognitive dysfunction (Figure 6). ${ }^{4,13-16}$ Generally, drugs that block D1 receptors (or overstimulate them) would therefore theoretically dysregulate D1 receptors, and hypothetically this would lead to cognitive dysfunction. ${ }^{4,13-16}$ Cognitive dysfunction would certainly be an undesired action of those agents that block D1 receptors, especially in patients with disorders already characterized by cognitive dysfunction, such as schizophrenia and bipolar disorder. Some of the drugs that potentially exhibit clinically relevant blockade of D1 receptors also block to varying degrees muscarinic cholinergic and histamine receptors, ${ }^{3}$ adding to their theoretical potential for cognitive dysfunction. Whether there are any potential benefits of D1 antagonism remains to be shown, although it is possible that blocking D1 receptors while blocking D2 receptors might diminish drug-induced parkinsonism.

\section{Drugs with Effective D3 Antagonism/Partial Agonism (Plus D2 Antagonism/Partial Agonism)}

Drug affinities for D3 receptors for many agents in Table 1 are about the same or higher than their affinities for D2 receptors (Figure 2), but they are mostly lower 


\section{BRAINSTORMS-Clinical Neuroscience Update}

Figure 6. Antagonist effects at D1 dopamine receptors are illustrated here. These include reducing dopamine neurotransmission in the prefrontal cortex, and theoretically causing cognitive dysfunction by "de-tuning" D1 receptor activity.

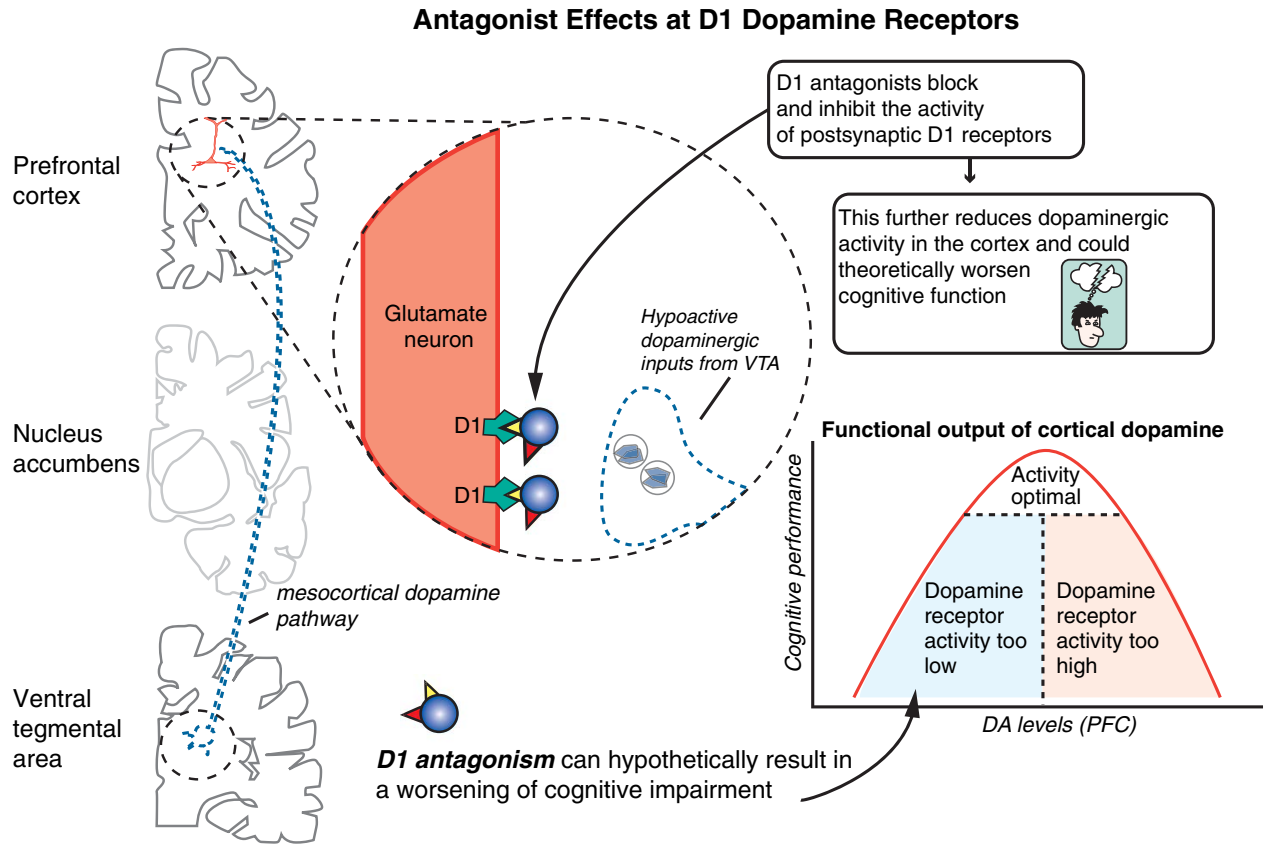

Figure 7. Antagonist/partial agonist effects at D2 dopamine receptors are illustrated here. These are well-known antipsychotic actions at D2 receptors in the nucleus accumbens, and also motor side effects at D2 receptors in the motor striatum.

Antagonist/Partial Agonist Effects at D2 Dopamine Receptors

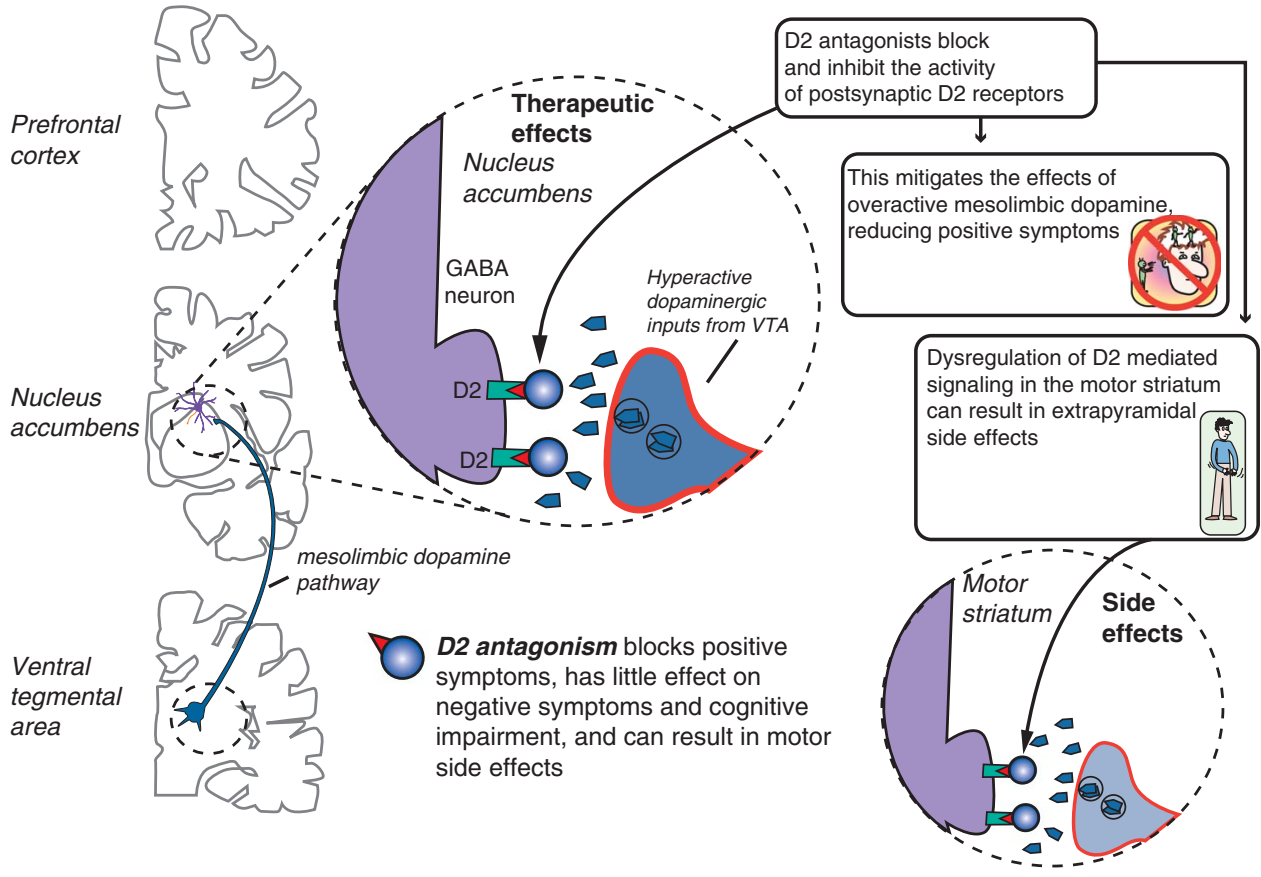




\section{BRAINSTORMS -Clinical Neuroscience Update}

Figure 8. Antagonist/partial agonist effects at D3 receptors are illustrated here. Theoretically, D3 actions disinhibit dopamine release in the prefrontal cortex, which could improve negative symptoms, cognition, and mood.

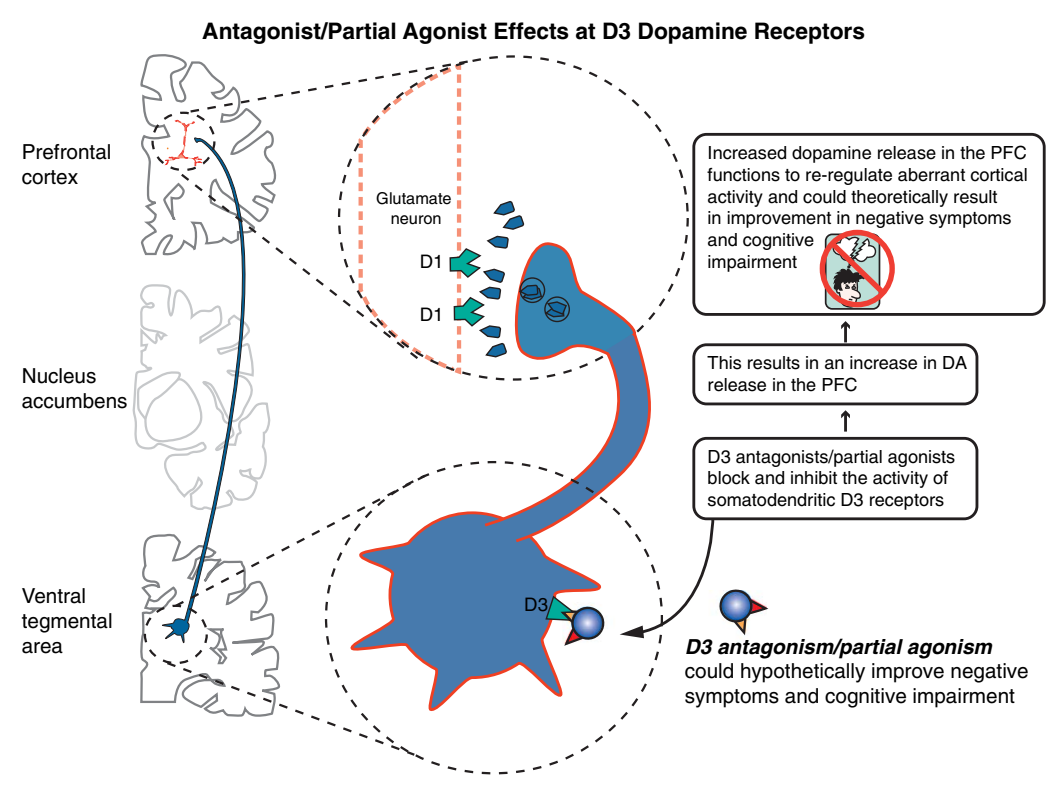

Figure 9. Three classes of drugs that bind to dopamine receptors. Eight agents bind predominantly to D2 receptors alone, 3 agents bind as well to D1 receptors, and 2 agents bind D3 receptors as well as D2 receptors.

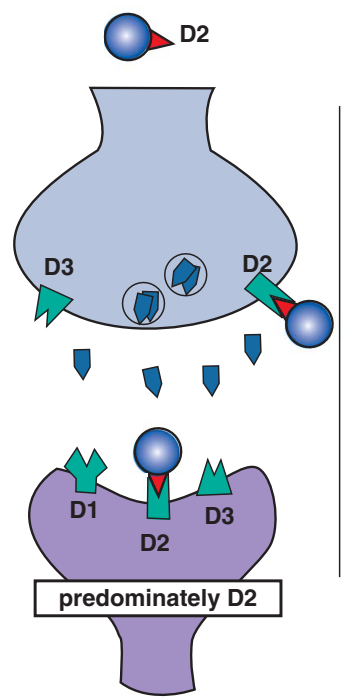

brexpiprazole paliperidone aripiprazole risperidone ziprasidone iloperidone lurasidone quetiapine

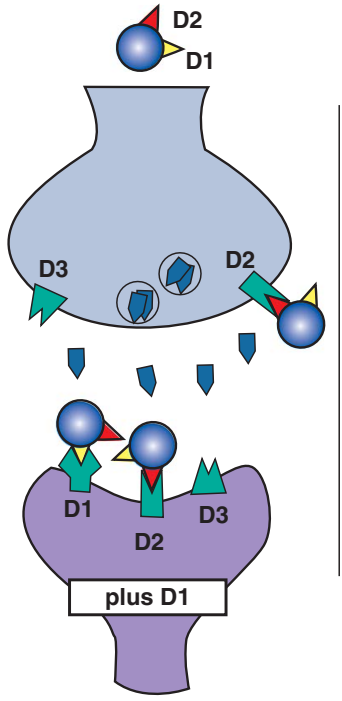

asenapine olanzapine clozapine

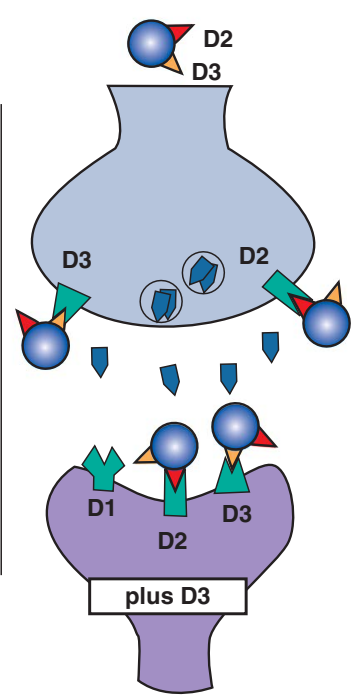

cariprazine blonanserin 
BRAINSTORMS-Clinical Neuroscience Update

Table 1. Three Classes of Dopamine Receptor Binding Drugs for Psychosis and Mood

\begin{tabular}{|c|c|c|c|c|c|c|c|c|c|}
\hline Ki (nM) & D3 & D2 & D1 & $\begin{array}{c}\text { DA/D3 } \\
\text { Order of } \\
\text { Magnitude }\end{array}$ & $\begin{array}{c}\text { DA/D2 } \\
\text { Order of } \\
\text { Magnitude }\end{array}$ & $\begin{array}{c}\text { DA/D1 } \\
\text { Order of } \\
\text { Magnitude }\end{array}$ & $\begin{array}{c}\text { D2/D3 } \\
\text { Order of } \\
\text { Magnitude }\end{array}$ & $\begin{array}{c}\text { D1/D2 } \\
\text { Order of } \\
\text { Magnitude }\end{array}$ & $\begin{array}{c}\text { D1/D3 } \\
\text { Order of } \\
\text { Magnitude }\end{array}$ \\
\hline Dopamine (DA) & 60 & 540 & 1766 & 0 & 0 & 0 & 1 & 1 & 2 \\
\hline \multicolumn{10}{|c|}{ D2 BINDING ONLY } \\
\hline Brexpiprazole* & 1.1 & 0.3 & 164 & 1 & 3 & -1 & -1 & 3 & 2 \\
\hline Paliperidone & 2.6 & 1.4 & 41 & 1 & 2 & 2 & 0 & 2 & 1 \\
\hline Aripiprazole & 4.6 & 2.3 & 1173 & 1 & 2 & 0 & 0 & 3 & 3 \\
\hline Risperidone & 7.3 & 3.7 & 327 & 1 & 2 & 1 & 0 & 2 & 2 \\
\hline Ziprasidone & 7.3 & 4.75 & 80 & 1 & 2 & 2 & 0 & 1 & 1 \\
\hline Iloperidone & 10.5 & 8.3 & 129 & 0 & 2 & 1 & -1 & 2 & 1 \\
\hline Lurasidone $^{* *}$ & 15.7 & 0.66 & 262 & 0 & 3 & 1 & -2 & 3 & 1 \\
\hline Quetiapine & 394 & 437 & 1096 & -1 & 0 & 0 & 0 & 1 & 1 \\
\hline \multicolumn{10}{|c|}{ D2 + D1 BINDING } \\
\hline Asenapine & 1.8 & 1.7 & 2.9 & 1 & 2 & 3 & 0 & 0 & 0 \\
\hline Olanzapine & 38.05 & 30.75 & 56.6 & 0 & 1 & 2 & 0 & 0 & 0 \\
\hline Clozapine & 310 & 147 & 240 & -1 & 0 & 1 & 0 & 0 & 0 \\
\hline \multicolumn{10}{|c|}{ D2 + D3 BINDING } \\
\hline Cariprazine $e^{* * *}$ & 0.09 & 0.49 & 1000 & 3 & 3 & -1 & 1 & 4 & 5 \\
\hline Blonanserin ${ }^{* * * *}$ & 0.494 & 0.142 & 1090 & 2 & 3 & 0 & 0 & 4 & 4 \\
\hline
\end{tabular}

All binding data from PDSP Ki database unless noted (5)

* Data from Frankel et al, 2017 (6); K. Meada (personal communication, Otsuka)

** Data from Greenberg et al, 2017 (7)

*** Data from N. Adham (personal communication, Allergan)

**** Data from Tenjin et al, 2013 (8)

than dopamine's affinity for the D3 receptor (Figure 5). This high affinity of endogenous dopamine for D3 receptors has been postulated to result in only minimal or no D3 receptor occupancy in dopamine-rich brain areas by any but those drugs with the most potent binding to D3, ie, those drugs with affinities that are even higher than that of dopamine itself for D3 receptors. ${ }^{17,18}$ Taken together, cariprazine and perhaps blonanserin (a drug for psychosis marketed in Japan $)^{6,19,20}$ may be the agents most likely to have clinically meaningful degrees of D3 receptor binding when dosed for psychosis. What are the implications of D3 binding?

Distribution of D3 receptors differs from that of both D1 and D2 receptors, with D3 receptors being localized predominantly in limbic areas. ${ }^{4,21,22}$ D3 receptors can be postsynaptic, presynaptic at axon terminals, or presynaptic at the somatodendritic area of certain dopamine neurons arising from the substantia nigra/ventral tegmentum. There are hardly any D3 receptors at all on dopamine terminals of the dorsal striatum (motor). Most areas of the brain that do express D3 receptors also express D2 receptors, so it can be difficult to determine which action to attribute to which receptor.

Since D3 receptors are unique among dopamine receptors in having a high affinity for dopamine, this suggests that dopamine may be occupying D3 receptors in the living brain for extended periods of time, leading to lots of activation of D3 autoreceptors, which would hold back the release of dopamine from nerve terminals. ${ }^{4,17,18}$ Thus, due to their high affinity for dopamine, D3 receptors, unlike D1 or D2 receptors, appear to be stimulated by low levels of tonic dopamine release to attenuate the effects of dopamine fluctuation related to bursts of phasic dopamine release (see Stahl ${ }^{4}$ for discussion of tonic and phasic dopamine release). ${ }^{4,17,18}$ Blocking this attenuation would disinhibit dopamine release and enhance neurotransmission. Theoretically, that would enhance dopaminergic neurotransmission, especially in brain areas such as the prefrontal cortex where dopamine release appears to be controlled by D3 receptors 


\section{BRAINSTORMS-Clinical Neuroscience Update}

(Figure 8). ${ }^{23-34}$ Also, blocking D3 receptors enhances acetylcholine release in the prefrontal cortex, which could also contribute to pro-cognitive actions. ${ }^{31,35}$

Current theories link a reduction of limbic dopamine release to anhedonia, depressive states, motivation, and pleasure. ${ }^{23-34}$ Consistent with this notion, in animal models D3 antagonism improves cognition, mood, and motivation (Figure 8). ${ }^{23-34}$ Early clinical results do suggest enhanced efficacy for negative symptoms of schizophrenia with the D3 preferring agent cariprazine. ${ }^{36}$ Much further research is required to follow up on these interesting therapeutic possibilities for D3 antagonist/partial agonist treatment of negative symptoms, mood, cognition, and even substance abuse.

\section{Conclusions}

Individualizing treatments for psychosis and mood involves finding the best therapeutic agent for a specific patient. Knowing the D1 and D3 dopamine receptor profiles of agents that act on D2 receptors-as well as the various additional receptors a given drug bindscan assist practitioners in matching the best therapeutic agent to the individual patient's symptom profile.

\section{References:}

1. Zohar J, Stahl S, Moller H-J, et al. Neuroscience Based Nomenclature. Cambridge, UK: Cambridge University Press; 2014.

2. Stahl SM. Using neuroscience for naming psychotropic drugs. CNS Spectr. 2015; 21(3): 219-220.

3. Stahl SM. Stahl's Essential Psychopharmacology: Neuroscientific Basis and Practical Application. 4th ed. Cambridge, UK: Cambridge University Press; 2013.

4. Stahl SM. Dazzled by the dominions of dopamine: clinical roles of D3, D2, and D1 receptors. CNS Spectr. 2017; 22(4): 305-311.

5. Roth BL. National Institute of Mental Health's Psychoactive Drug Screening Program (NIMH PDSP). http://pdsp.med.unc.edu.

6. Frankel JS, Schwartz TL. Brexpiprazole and cariprazine: distinguishing two new atypical antipsychotics from the original dopamine stabilizer aripiprazole. Ther Adv Psychopharmacol. 2017; 7(1): 29-41.

7. Greenberg WM, Citrome L. Pharmacokinetics and pharmacodynamics of lurasidone hydrochloride, a second-generation antipsychotic: a systematic review of the published literature. Clin Pharmacokinet. 2017, 56(5): 493-503.

8. Tenjin T, Miyamoto S, Nonmiya Y, et al. Profile of blonanserin for the treatment of schizophrenia. Neuropsychiatr Dis Treat. 2013; 9: 587-594.

9. Volkow ND, Wang G-J, Fowler JS, et al. Relationship between blockade of dopamine transporters by oral methylphenidate and the increases in extracellular dopamine: therapeutic implications. Synapse. 2002; 43(3): 181-187.

10. Abi-Dargham A, Gil G, Krystal J, et al. Increased striatal dopamine transmission in schizophrenia: confirmation in a second cohort. Am J Psychiatry. 1998; 155(6): 761-767.

11. Breier A, Su T-P, Saunders R, et al. Schizophrenia is associated with elevated amphetamine-induced synaptic dopamine concentrations: evidence from a novel positron emission tomography method. Proc Natl Acad Sci U S A. 1997; 94(6): 2569-2574.
12. Farde L, Nordstrom A-L, Wiesel F-A, Pauli S, Halldin C, Sedvall G Positron emission tomographic analysis of central D1 and D2 dopamine receptor occupancy in patients treated with classical neuroleptics and clozapine: relation to extrapyramidal side effects. Arch Gen Psychiatry. 1992; 49(7): 538-544.

13. Cools R, D'Esposito M. Inverted-U-shaped dopamine actions on human working memory and cognitive control. Biol Psychiatry. 2011; 69(12): e113-125.

14. Arnsten AFT, Cai JX, Murphy BL, Goldman-Rakic PS. Dopamine D1 receptor mechanisms in the cognitive performance of young adult and aged monkeys. Psychopharmacology (Berl). 1994; 116(2): 143-151.

15. Arnsten AFT, Goldman-Rakic PS. Noise stress impairs prefrontal cortical cognitive function in monkeys: evidence for a hyperdopaminergic mechanism. Arch Gen Psychiatry. 1998; 55(4): 362-368.

16. Arnsten AFT, Girgis RR, Gray DL, Mailman RB. Novel dopamine therapeutics for cognitive deficits in schizophrenia. Biol Psychiatry. 2017; 81(1): 67-77.

17. Nakajima S, Gerretson P, Tekeuchi H, et al. The potential role of dopamine D3 receptor neurotransmission in cognition. Eur Neuropsychopharmacol. 2013; 23(8): 799-813.

18. Gross G, Drescher K. The role of dopamine D3 receptors in antipsychotic activity and cognitive functions. Handb Exp Pharmacol. 2012; (213): 167-210.

19. Tenjin T, Miyamoto S, Miyake N, et al. Effect of blonanserin on cognitive function in antipsychotic-naïve first episdoe schiozphrenia. Hum Psychopharmacol. 2012; 27(1): 90-100.

20. Hida $\mathrm{H}$, Mouri $\mathrm{A}$, Mori $\mathrm{K}$, et al. Blonanserin ameliorates phencyclidine-induced visual-recognition memory deficits: the complex mechanism of blonanserin action involving $\mathrm{D}_{3}-5-\mathrm{HT}_{2} \mathrm{~A}$ and $\mathrm{D}_{1}$-NMDA receptors in the $\mathrm{mPFC}$. Neuropsychopharmacology. 2015; 40(3): 601-613.

21. Gurevich EV, Joyce JN. Distribution of dopamine D3 receptor expressing neurons in the human forebrain: comparison with D2 receptor expressing neurons. Neuropsychopharmacology. 1999; 20(1): 60-80.

22. Sokoloff P, Le Foll B. The dopamine D3 receptor, a quarter century later. Eur J Neurosci. 2017; 45(1): 2-19.

23. Nestler EJ, Carlezon WA Jr. The mesolimbic dopamine reward circuit in depression. Biol Psychiatry. 2006; 59(12): 1151-1159.

24. Volkow ND, Baler RD. NOW vs LATER brain circuits: implications for obesity and addiction. Trends Neurosci. 2015; 38(6): 345-352.

25. Francis TC, Lobo MK. Emerging role for nucleus accumbens medium spiny neuron subtypes in depression. Biol Psychiatry. 2017; 81(8): 645-653.

26. Sokoloff P, Giros B, Martres MP, Bouthenet ML, Schwartz JC. Molecuar clonic and characterization of a novel dopamine receptor (D3) as a target for neuroleptics. Nature. 1990; 347(6289): 146-151.

27. Tritsch NX, Sabatini BL. Dopaminergic modulation of synaptic transmission in cortex and striatum. Neuron. 2012; 76(1): 33-50.

28. Beaulieu JM, Gainetdinov RR. The physiology, signaling, and pharmacology of dopamine receptors. Pharmacol Rev. 2011; 63(1): 182-217.

29. Leggio GM, Bucolo C, Platania CB, Salomone S, Drago F. Current drug treatments targeting dopamine D3 receptor. Pharmacol Ther. 2016; 165: 164-177.

30. Grace AA. Dysregulation of the dopamine system in the pathophysiology of schizophrenia and depression. Nat Rev Neurosci. 2016; 17(8): 524-532. 
31. Gobert A, Rivet JM, Audinot V, et al. Functional correlates of dopamine $\mathrm{D} 3$ receptor activation in the rat in vivo and their modulation by the selective antagonist, (+)-S 14297: II. Both D2 and "silent" D3 autoreceptors control synthesis and release in mesolimbic, mesocortical and nigrostriatal pathways. J Pharmacol Exp Ther. 1995; 275: 899-913.

32. Watson DJ, Loiseau F, Ingallinesi M, Millan MJ, Marsden CA, Fon KC. Selective blockade of dopamine D3 receptors enhances while D2 receptor antagonism impairs social novelty discrimination and novel object recognition in rats: a key role for the prefrontal cortex. Neuropsychopharmacology. 2012; 37(3): 770-786.

33. Watson DJ, Marsden CA, Millan MJ, Fone KAC. Blockade of dopamine $D_{3}$ but not $D_{2}$ receptors reverses the novel object discrimination impairment produced by post-weaning social isolations: implications for schizophrenia and its treatment. Int J Neuropsychopharmacol. 2012; 15(4): 471-484.
34. Kiss B, Horváth A, Némethy Z, et al. Cariprazine (RGH-188), a dopamine $\mathrm{D}(3)$ receptor-preferring, $\mathrm{D}(3) / \mathrm{D}(2)$ dopamine receptor antagonist-partial agonist antipsychotic candidate: in vitro and neurochemical profile. J Pharmacol Exp Ther. 2010; 333(1): 328-340.

35. Lacroix LP, Ceolin L, Zocchi A, et al. Selective dopamine D3 receptor antagonists enhance cortical acetylcholine levels measured with high-performance liquid chromatography/tandem mass spectrometry without anti-cholinesterases. J Neurosci Methods. 2006; 157(1): 25-31.

36. Németh G, Laszlovsky I, Czobor P, et al. Cariprazine versus risperidone monotherapy for treatment of predominant negative symptoms in patients with schizophrenia: a randomized, doubl-bline, controlled trial. Lancet. 2017; 389(10074): 1103-1113. 